\title{
EFFECT OF PYRIDOXINE ON TRYPTOPHAN METABOLISM IN RHEUMATOID ARTHRITIS
}

\author{
ISOBEL M. BETT \\ Rheumatic Diseases Unit, Northern General Hospital, Edinburgh
}

In a previous paper (Bett, 1962), it was reported that a majority of patients with rheumatoid arthritis excreted abnormal amounts of the tryptophan metabolites, 3-hydroxyanthranilic acid and kynurenine. In these experiments the most striking difference between control subjects and patients with rheumatoid arthritis was in the urinary kynurenine output after a loading dose of L-tryptophan. This work has been extended in the present investigation and the possible relationship between this abnormality and the duration or activity of disease has been explored.

Kynureninase, one of the enzymes responsible for kynurenine catabolism, is dependent on pyridoxal phosphate (Jakoby and Bonner, 1953). For this reason, the effect of administration of pyridoxine on kynurenine output after tryptophan loading has been studied.

\section{Material and Methods}

Urine was collected over 24-hour periods from 43 patients with rheumatoid arthritis. A second 24-hour collection of urine was obtained from these patients after ingestion of $3 \mathrm{~g}$. L-tryptophan.

Two groups of patients were studied: a series of ten from whom salicylates were withheld during the collections and for the preceding $\mathbf{4 8}$ hours, and a series of 33 who received salicylates ( 4 to $6 \mathrm{~g}$. daily) throughout the experiments.

The 21 control subjects were members of the staff of the Northern General Hospital, Edinburgh. They were subdivided into two groups: three with a family history of rheumatoid arthritis and eighteen without.

Kynurenine was measured, as previously, by the method of Tompsett (1959). To eliminate effects from sedative drugs, particularly dichloralphenazone, a "blank" was prepared from urine collected in the 24 hours preceding the loading with tryptophan.

In some patients and control subiects the measurements of kynurenine output after L-tryptophan were repeated at intervals of 1 and 40 weeks apart and were found to be reasonably constant for each individual (Fig. 1).

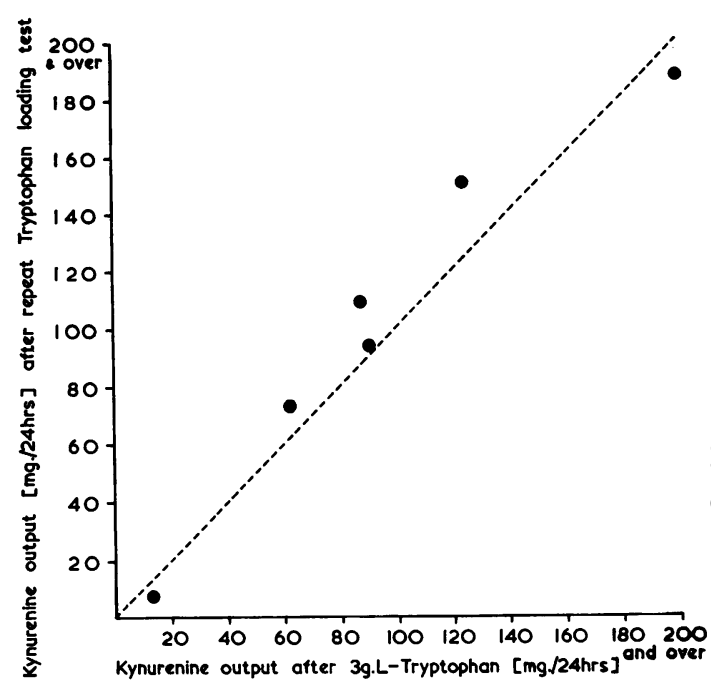

Fig. 1.-Duplicate tryptophan loading tests in some control subjects and patients with rheumatoid arthritis.

\section{Results}

The kynurenine output after loading with Ltryptophan was measured in the 21 control subjects, three with a family history of rheumatoid arthritis; the results are shown in Fig. 2A (opposite). With the exception of the three controls from Tompsett's series (Fig. 2A) who received a dose of $5 \mathrm{~g}$., the loading dose in each subject was $3 \mathrm{~g}$. L-tryptophan. The mean kynurenine output was $29.7 \mathrm{mg}$. $/ 24 \mathrm{hrs}$ ( 2.0 to $128.5 \mathrm{mg} . / 24 \mathrm{hrs}$ ).

Similar tests were performed in the 43 patients with rheumatoid arthritis; in this group the mean kynurenine output after loading was $84.2 \mathrm{mg}$./ $24 \mathrm{hrs}(10.6$ to $282.4 \mathrm{mg}$. $/ 24 \mathrm{hrs})$. In this respect, the ten patients from whom salicylates were withheld did not differ significantly from the remaining 33 who continued on salicylates during the experiments (Fig. 2B, opposite). 
[A] CONTROL SUBJECTS
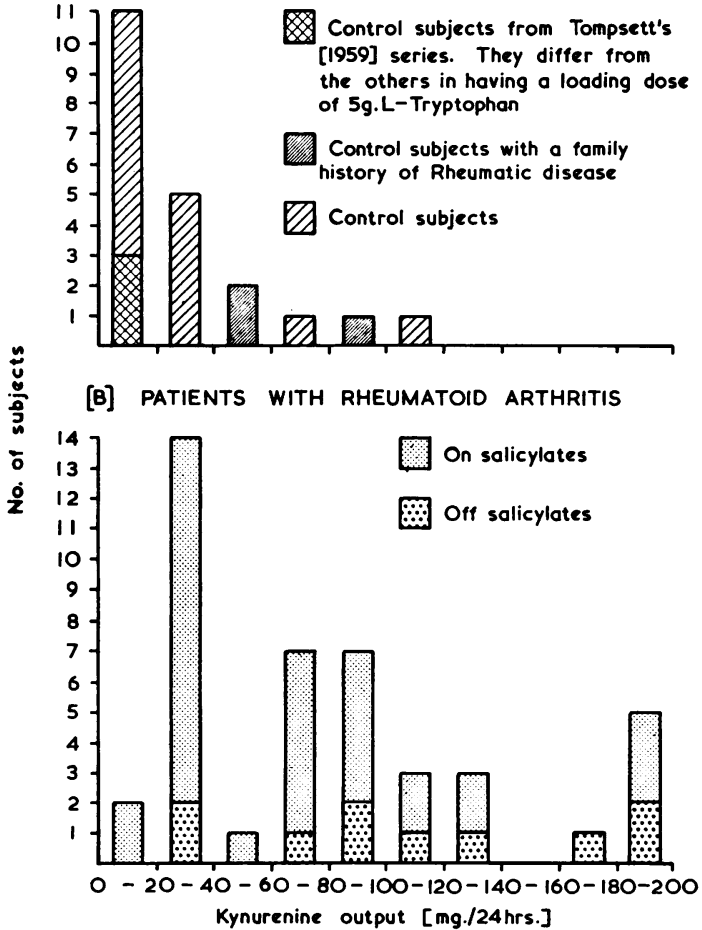

Fig. 2.-Kynurenine output (A) in control subjects and (B) in patients with rheumatoid arthritis, after $3 \mathrm{~g}$. L-tryptophan.

In 23 patients the tryptophan loading tests were repeated after the administration of 200 to $800 \mathrm{mg}$. pyridoxine. These results are shown in Fig. 3.

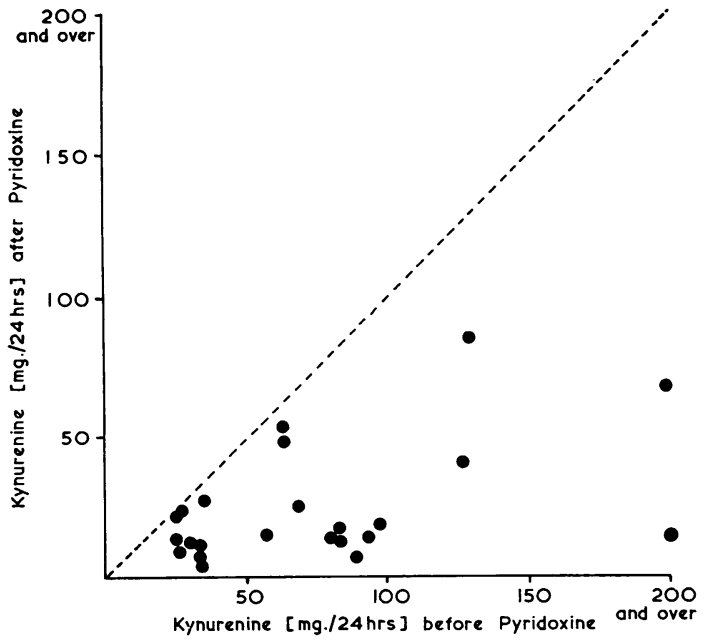

Fig. 3.-Effect of pyridoxine administration on kynurenine output in patients with rheumatoid arthritis.
The mean kynurenine output after pyridoxine was $24.9 \mathrm{mg} . / 24 \mathrm{hrs}(4 \cdot 3$ to $85 \cdot 1 \mathrm{mg} . / 24 \mathrm{hrs})$. It was found initially that kynurenine output after tryptophan decreased in some patients when they were given an oral dose of pyridoxine of $100 \mathrm{mg}$. daily for 5 days. In others this amount of pyridoxine had no effect, but these subjects did respond after an additional dose of pyridoxine, $50 \mathrm{mg}$. daily for 3 days by intramuscular injection. With two exceptions, the remaining patients in this present series were given oral pyridoxine, $100 \mathrm{mg}$. daily for 7 days, followed by intramuscular pyridoxine $50 \mathrm{mg}$. daily for 3 days. One patient received $50 \mathrm{mg}$. intramuscular pyridoxine daily for 4 days, and one for 5 days.

Tryptophan loading tests were repeated in one patient 1 week, and in another 6 weeks, after administration of pyridoxine was completed. These results are shown in Table I.

$$
\text { TABLE I }
$$

EFFECT OF PYRIDOXINE WITHDRAWAL ON KYNURENINE OUTPUT AFTER TRYPTOPHAN LOADING IN TWO PATIENTS

\begin{tabular}{|c|c|c|}
\hline \multicolumn{3}{|c|}{ Kynurenine Output (mg./24 hrs) } \\
\hline $\begin{array}{l}\text { Initial } \\
\text { Test }\end{array}$ & $\begin{array}{l}\text { Test during Pyridoxine } \\
\text { Administration }\end{array}$ & $\begin{array}{l}\text { (a) Test 1 week after } \\
\text { Pyridoxine withdrawal } \\
\text { (b) Test 6 weeks after } \\
\text { Pyridoxine withdrawal }\end{array}$ \\
\hline $\begin{array}{r}87 \cdot 9 \\
232 \cdot 2\end{array}$ & $\begin{array}{r}7 \cdot 4 \\
12 \cdot 0\end{array}$ & $\begin{array}{l}\text { (a) } 109 \cdot 3 \\
\text { (b) } 187 \cdot 9\end{array}$ \\
\hline
\end{tabular}

The effect of long-term administration of pyridoxine on kynurenine output was studied in two patients who were given $50 \mathrm{mg}$. intramuscular pyridoxine daily for 22 days. Tryptophan loading tests were performed before and at 4-day intervals during the administration of pyridoxine. The results of these experiments are shown in Table II.

$$
\text { TABLE II }
$$

THE EFFECT OF PROLONGED INTRAMUSCULAR PYRIDOXINE ON KYNURENINE OUTPUT AFTER TRYPTOPHAN LOADING IN TWO PATIENTS

\begin{tabular}{|c|c|c|c|c|}
\hline \multirow{2}{*}{$\begin{array}{c}\text { Initial } \\
\text { Test }\end{array}$} & \multicolumn{4}{|c|}{ After $50 \mathrm{mg}$. Intramuscular Pyridoxine daily for: } \\
\hline & 4 days & 10 days & 16 days & 22 days \\
\hline $\begin{array}{r}43 \cdot 2 \\
111 \cdot 8\end{array}$ & $\begin{array}{l}15 \cdot 7 \\
42 \cdot 4\end{array}$ & $\begin{array}{l}15 \cdot 3 \\
43 \cdot 9\end{array}$ & $\begin{array}{l}12 \cdot 8 \\
22 \cdot 2\end{array}$ & $\begin{array}{l}13 \cdot 1 \\
32 \cdot 5\end{array}$ \\
\hline
\end{tabular}

Kynurenine Output after Tryptophan Loading (mg./24 hrs)

Following L-tryptophan, the mean kynurenine output of the 23 females in the rheumatoid group tended to be higher than that of the twenty males, but the difference was not statistically significant 
$(P=0 \cdot 2)$. There was no correlation between the kynurenine output and the age of the patient, the duration of the disease, or factors measuring the activity or severity of the disease. These findings are summarized in Table III.

\section{Discussion}

It has been found that oral administration of L-tryptophan to patients with rheumatoid arthritis is followed in a majority of cases by the excretion of abnormally large amounts of kynurenine. This abnormality is apparently unaffected by salicylate therapy. Two patients who had had no previous salicylate therapy had very high kynurenine outputs, suggesting that this abnormality is not a long-term metabolic effect of the drug.

There was no demonstrable correlation between kynurenine output and the duration, activity, or severity of the disease.

It is known that pyridoxal phosphate is involved in tryptophan metabolism at the kynureninase level. Price, Brown, Rukavina, Mendelson, and Johnson (1957) observed that administration of pyridoxine tended to correct abnormalities of tryptophan metabolism described by them in patients with scleroderma. They found raised urinary outputs of $\frac{2}{3}$ kynurenine, hydroxykynurenine, kynurenic acid, and $\mathbf{N} \alpha$-acetyl kynurenine in their patients. $\bar{n}$ Xanthurenic acid output, usually used as a measure $\Rightarrow$. of pyridoxine deficiency, was not unduly raised. $\stackrel{?}{\rightarrow}$ In preliminary experiments here, 3-hydroxykynur-으 enine, kynurenic acid, and xanthurenic acid have $\overline{\bar{O}}$ been measured in addition to kynurenine in a series $\frac{\bar{\rho}}{\overline{ }}$ of control subjects and patients with rheumatoid $\mathbb{Q}$ arthritis. Increased outputs of all metabolites except xanthurenic acid were observed in the patientswith rheumatoid arthritis. This work is being. extended and is to be published elsewhere.

Price, Brown, and Larson (1956) demonstrated $\stackrel{\omega}{\circ}$ that isoniazid used to treat patients with tuberculosis produced abnormalities in tryptophan metabolismin which could be corrected by administration of pyridoxine. It is of some interest here thatiw McKusick and Hsu (1961) have reported the development of a syndrome resembling rheumatoido arthritis in a series of patients with tuberculosisreceiving isoniazid and PAS. Clinical improvement followed withdrawal of the drug or, in some instances, the concurrent administration of pyri- 3 doxine. The urinary output of 5 hydroxy-indolyl- $\Phi$

TABLE III

RELATIONSHIP BETWEEN KYNURENINE OUTPUT AFTER TRYPTOPHAN LOADING AND VARIOUS OTHER FACTORS

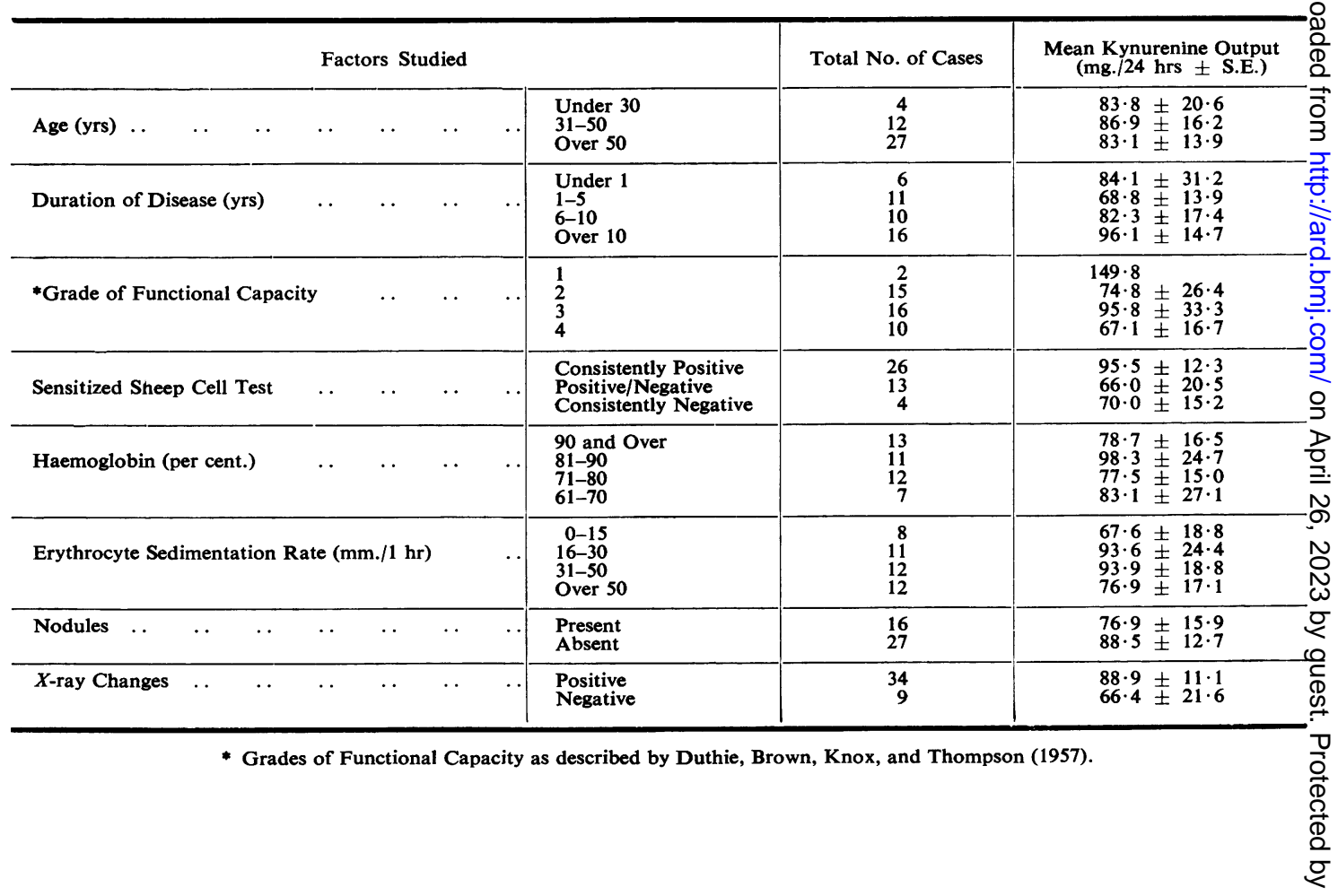


acetic acid was found to be elevated in these patients and was decreased by pyridoxine administration. These authors did not report a detailed analysis of the urinary metabolites of tryptophan. In the present study prolonged administration of pyridoxine to patients with rheumatoid arthritis caused a sustained fall in the output of kynurenine after L-tryptophan; the metabolite was again excreted in increased amounts immediately after pyridoxine was withdrawn. Clinical effects of pyridoxine administration were not assessed in these patients. The mechanism of the observed metabolic effects of the vitamin is still obscure and merits additional investigation.

In the control group high levels of kynurenine excretion were observed in three subjects who had a family history of rheumatic disease. This finding may be relevant to the reported familial incidence of the disease (Lawrence and Ball, 1958), and has prompted a study, now in progress, of tryptophan metabolism in relatives of patients with rheumatoid arthritis.

\section{Summary}

Kynurenine output after L-tryptophan was shown to be increased in the majority of patients with rheumatoid arthritis. This abnormality was unrelated to the duration, activity, or severity of the disease.

Administration of large doses of pyridoxine orally and/or intramuscularly produced a reduction in kynurenine output after tryptophan in a majority of patients.

I am grateful to Dr. J. J. R. Duthie and Dr. J. L. Potter for their helpful advice and criticism. I also wish to thank Dr. S. L. Tompsett for permission to include three of his control results.

This research was supported by a grant from the Medical Research Council to Dr. J. J. R. Duthie, and, during the period in which it was carried out, the
Rheumatic Diseases Unit was also in receipt of grants from the Nuffield Foundation, the Empire Rheumatism Council, and Boots' Pure Drug Company Ltd.

\section{REFERENCES}

Bett, I. M. (1962). Ann. rheum. Dis., 21, 63.

Duthie, J. J. R., Brown, P. E., Knox, J. D. E., and Thompson, M. (1957). Ibid., 16, 411.

Jakoby, W. B., and Bonner, D. M. (1953). J. biol. Chem., 205, 699.

Lawrence, J. S., and Ball, J. (1958). Ann. rheum. Dis., $17,160$.

McKusick, A. B., and Hsu, J. M. (1961). Arthr. and Rheum., 4, 426.

Price, J. M., Brown, R. R., and Larson, F. C. (1956). Fed. Proc., 15, 330.

Price, J. M., Brown, R. R., Rukavina, J. G., Mendelson, C., and Johnson, S. A. M. (1957). J. invest. Derm., 29, 289.

Tompsett, S. L. (1959). Clin. chim. Acta, 4, 411.

L'effet de la pyridoxine sur le métabolisme du tryptophane dans l'arthrite rhumatismale

RÉSUMÉ

On démontre que l'élimination de kynurénine après l'ingestion de L-tryptophane se trouve augmentée dans la plupart des cas atteints d'arthrite rhumatismale.

L'administration de fortes doses de pyridoxine par voie orale et/ou intramusculaire produisait une diminution de l'élimination de kynurénine après l'ingestion de tryptophane chez la plupart des malades.

\section{Efecto de piridoxina sobre el metabolismo del triptófano en la artritis reumatoide}

\section{SUMARIO}

Se demuestra que la eliminación de kynurenina después de ingestión de L-triptófano se ve aumentada en la mayoría de los enfermos con artritis reumatoide.

Administración de fuertes dosis de piridoxina por vía oral $\mathrm{y} / \mathrm{o}$ intramuscular producía una eliminación disminuida de kynurenina después de ingestión de triptófano en la mayoría de los enfermos. 